対応している。

保持圧力の大きさは金型内の樹脂圧力挙動の静圧部分 に大きな影響を与え，同時に保持圧力を保つためのクッ ション量, 初期充てん量および保持圧時間の長さも無視 できない。一般には成形条件は必ずしもこれらの圧力変 化に十分な考慮が払われて設定されたものとは思えず， その原因も個々の要因の意味が正確に把握されていない ことによるものと考えられ，金型内での樹脂圧力挙動の 測定の必要性と重要性もこの意味から再認識されなけれ ばならない。

\section{4. 結論}

成形機油圧回路で設定した保持圧力は必ずしもノズル
での樹脂圧力ではなく,クッション量, 初期充てん量等 の樹脂供給量的要因で金型内の樹脂圧力は著しく変わ る。保持圧力の大きさは静圧の大きさと残存時間に影響 を及ぼし，その増大は成形品重量を増加させゲイトシー ル時間を短縮する。初期充てん量は静圧のみならず場合 によっては流動圧にも影響し，過多のときは鋳張りの原 因となる。クッション量はノズルでの保持圧力の継続時 間を支配し，その量が少ないときは設定圧力と実際の樹 脂圧力には大きな相違が生じる。

\section{文献}

1) 天野 修：搞化, 28, 482 (1971)

2) 天野 修: 高化, 28, 493 (1971)

高密度ポリエチレンの射出成形における成形収縮率*1

（受付1971年 6 月 24 日・揭載決定1971年 9 月 10 日）

天 野修*

要 旨 HDPE の射出成形品の成形収縮は金型内の樹脂圧力挙動, 成形方法および成形条件に 強く依存する。本報ではクッション量, 初期充てん量, スクリュー前進時間および保持圧力が成形 収縮に及浔す影響を検討した。この揚合保持圧時間中の保持圧力を一定に保っため, クッションを 用いた。

保持圧力は金型内の圧カプロフィルの静圧に大きな影響を与え，収縮率を大きく変化させる。保 持圧力の増大は樹脂の流れ方向おょびそれと直角方向の収縮率を減少させるが，収縮率の異方性を も增大させる。

収縮率と圧力の残存時問から得られる固化時間は加熱筒温度および金型温度の上昇により延長さ れるが,これらは計算値とかなりよい一致を示す。収縮率の異方性をもたらす流動配向は樹脂温度 と充てん過程での推進力に強く支配されていると思われる。

\section{1. 緒言}

高密度ポリエチレン (HDPE) の射出成形品の成形收 縮は金型に充てんされた樹脂量, 寸なわち成形品重量に 大きく依存し，同時にキャビティー内の樹脂圧力挙動と 密接な関係をもつことは本研究の第 2 報1に述べたとお りである。第 3 報2) においてクッション量, 初期充てん 量, スクリュー前進時間および保持圧力が金型キャビテ ィー内の樹脂圧力挙動に及ぼす影響について述べたが， このときの成形品について収縮率を測定すれば上記成形 要因の成形収縮に及ぼす影響を知ることができ，射出成

\footnotetext{
* 日石樹脂化学加工研究所（川崎市千鳥町 15) $* 1$ 本研究を「高密度ポリエチレンの射出成形に関する研究」第 4 報と
する。
}

形における成形条件の意味をより明確にできるのみなら す，実用上で成形収縮率と成形条件との関倸についての 知見が得られるものと期待される。

\section{2. 方法}

クッション量, 初期充てん量, スクリュー前進時間お よび保持圧力を変えて成形した平板について，樹脂の流 れ方向 (MD) およびそれと直角方向 (TD) で収縮率を 求め, また収縮率と強い関係をもつ成形品厚みおよび密 度を第 2 報 ${ }^{1}$ に詳細に述べた方法に従って測定した。成 形機，金型，樹脂，成形方法および成形条件は第 3 報2》 のとおりである。

\section{3. 結果およひ考察}




\section{1 クッション量, 初期充てん吾およびスクリュー} 前進時間の影卙

保持圧力を $600 \mathrm{~kg} / \mathrm{cm}^{2}$ に設定しクッション量を変え たときの TD 収縮率の成形品内の位置による変化は Fig. 1 に示したとおり，クッション量の增加とともに低下し クッションストローク $5 \mathrm{~mm}$ で飽和する。これは前報2 の圧カプロフィルおよび成形品重量に変化がみられなく なるのと対応する。またゲイトから $70 \mathrm{~mm}$ の距離の No. 2 の位置で TD 収縮率は最も大きく変化するが, 圧 カプロフィル的にも圧力の残存時間がクッション量の增 加とともに著しく延長される。MD の収縮率の変化は非 常に小さく,クッションストローク $3 \mathrm{~mm}$ 程度まではわ ずかに減少するが，その後はほぼ一定となる。

Fig. 2 に MD および TD の各位置の収縮率の初期充 てん量による変化を示したが，MD では初期充てん量の 増加とともに収縮率が減少するが，TD では位置により 著しく異なる。ゲイト近くの TD-1 では初期充てん量に ほとんど無関倸で，これはNo.1 の圧カプロフィルにお いて圧力の残存時間が初期充てん量に無関係なのと対応 する。TD-2 TD-5 では初期充てん量の増加とともに 収縮率が増大し，ある量で最大となり，それ以上では逆 に減少する傾向を示すが，収縮率が最大となる初期充て ん量はゲイトから遠去かるほど小さくなる。No. 2 No. 5 の各位置の圧カプロフィルでも樹脂圧力の残存時間が 収縮率の変化と同じ傾向を示している。成形品重量に変 化がみられない $42 \mathrm{~g}$ 付近までの収縮率の変化は $\mathrm{MD}$ の 减少と TD の増加が互いに相殺し合ったものと思われ る。これらの変化はキャビティーが樹脂で完全に充てん される時間（樹脂温度）とも関連し, 初期充てん量が少 ないとキャビティーが完全充てんされるまでにかなりの 時間を要し, その間にNo. 2 以遠の位置では樹脂温度の

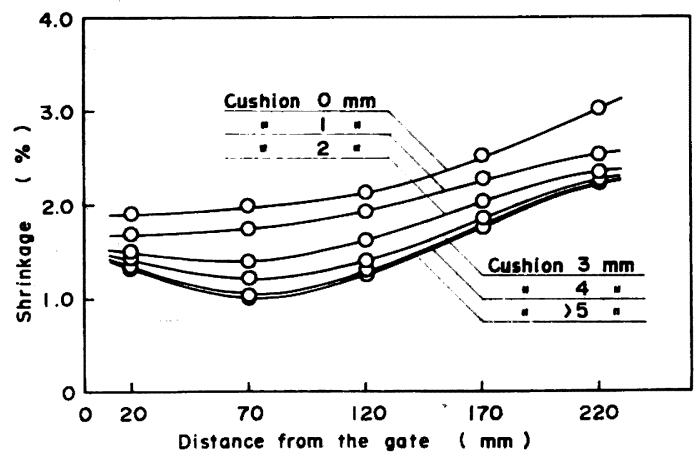

Molding conditions

Cylinder temperature: $230^{\circ} \mathrm{C}$, Mold temper ature: $50^{\circ} \mathrm{C}$, Injection pressure: $1000 \mathrm{~kg} / \mathrm{cm}^{2}$, Holding pressure: $600 \mathrm{~kg} / \mathrm{cm}^{2}$

Fig. 1. Effects of cushion stroke on TD-mold shrinkages.

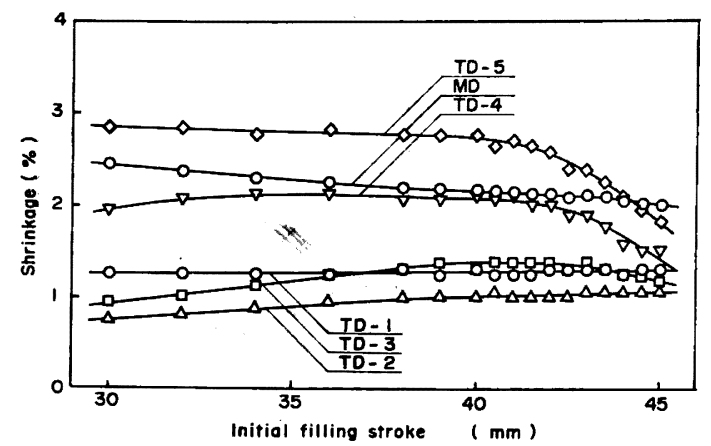

Molding conditions

Cushion stroke: $10 \mathrm{~mm}$, Other conditions are same as those of Fig. 1.

Fig. 2. Effects of initial filling stroke on mold shrinkages.

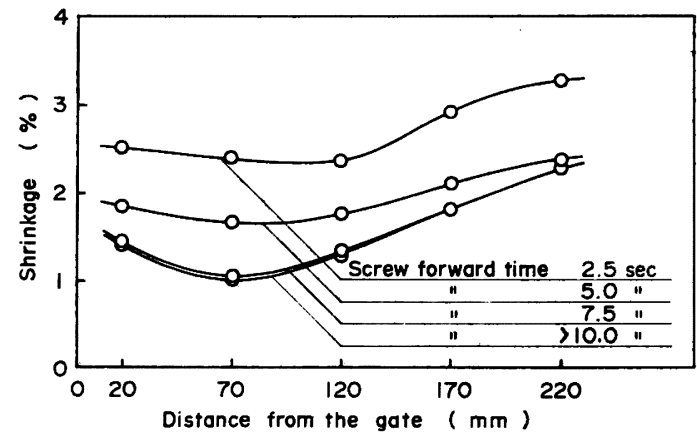

Molding conditions are same as those of Fig. 2.

Fig. 3. Effects of screw forward time on TD-mold shrinkages.

低下が起こるが，ゲイトに近い部分では圧力の伝達が十 分で固化するまで比較的高い圧力が保てるので收縮率が 低下するものと考えられる。しかし No.1 ではゲイトシ ールまで長時間にわたり高温の樹脂の流入が続き，ゲイ トシール時は溶融状態であることおよびゲイトシール時 の圧力が保持圧力で決まることから, 圧力プロフィルの 静圧の末端部分では初期充てん量の影響がみられず, 収 縮率にも変化が現われないものと考えられる。

スクリュー前進時間の MD 収縮率に及ほす影響は小 さいが，その延長とともに収縮率は減少し約 7.5 秒で一 定となる。TD収縮率は Fig. 3 に示したとおりゲイトか ら離れるほど短いスクリュー前進時間で変化がなくな る。これはゲイトから離れるほど短時間で圧カプロフィ ルに変化がみられなくなるのと対応し，保持圧時間中の 樹脂の補充が困難となることを示している。

\section{2 保持圧力の影響と固化時間}

保持圧力をパラメーターにとり TD 収縮率と金型内の 位置との関係を Fig. 4 に示したが, 保持圧力の増大とと 


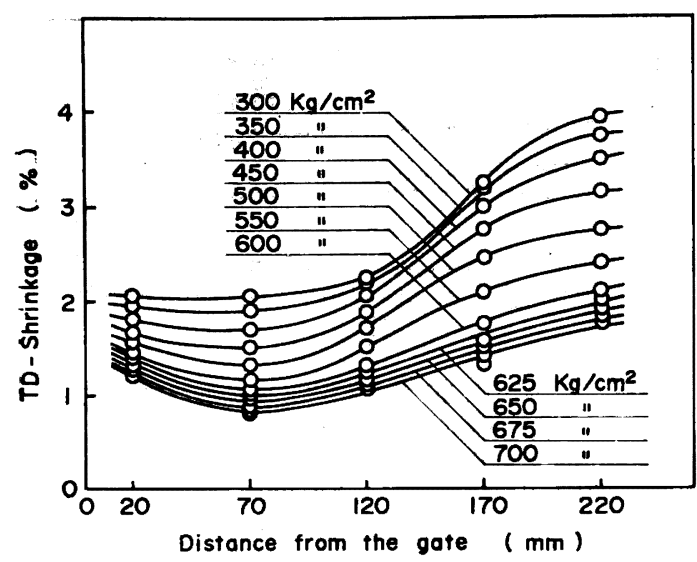

Molding conditions:

Cylinder temperature: $230^{\circ} \mathrm{C}$, Mold temperature: $50^{\circ} \mathrm{C}$, Injection pressure: $1000 \mathrm{~kg} / \mathrm{cm}^{2}$, Cushion stroke: $10 \mathrm{~mm}$

Fig. 4. Effects of holding pressure on TD-mold shrinkages.

もに収縮率は MD および TD ともに減少し，成形品重 量の増加および圧カプロフィルの変化と対応している。

No. $2 \sim$ No. 5 の位㯰では TD 収縮率と樹脂圧力の残 存時間との関係からキャビティー内での樹脂の固化時間 が求められる。成形条件をパラメーターにとり固化時間 をゲイトからの距離に対して示せば Fig. 5 のとおりで, 加熱筒温度および金型温度が上昇するほど固化時間が延 長される。加熱筒温度 $230^{\circ} \mathrm{C}$, 金型温度 $50^{\circ} \mathrm{C}$ の成形条件下 でクッションを用いないで成形した第 2 報1) の結果と本 報のそれを比較すると，ゲイトから離れたNo. 4 および No. 5 の位置で固化時間のかなりの遅れが認められる。

この原因としては第一に圧カプロフィル上から明らか

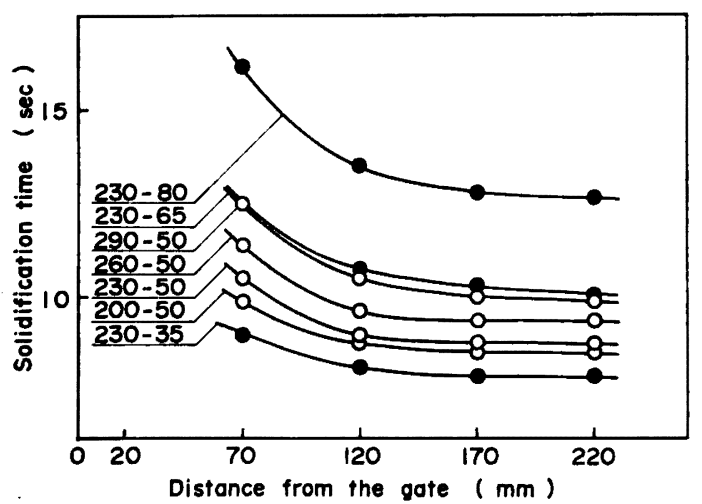

Numerals show cylinder temperature and mold temperature,

Fig. 5. Effects of cylinder temperature and mold temperature on solidification times.
なとおり初期充てん量の相違に基つく静圧最大值への到 達の遅れを，第二に保持圧時間中の有効圧力の増大によ る固化時の静压の増大とが考えられる。収縮率の大きさ がキャビティー内で圧力が解放されたときの樹脂温度で 決まるものと考えれば，樹脂圧力の増大は収縮率の減少 と同時に固化時間を延長させる作用をする。事実固化時 間における No. 2 No. 5 の各位置での TD 収縮率は本 報のそれがそれぞれ 1.20，1.30，1.60 および 1.85\%で 第 2 報1) $1.20 １ .25 ， 1.75$ および $2.25 \%$ とくらへ てキャビティー末端に近いほど減少しており，それら部 分での充てん樹脂量の増加を示している。

No. 2 の圧カプロフィルにおいてはゲイトシール前に 明らかに樹脂の流動の停止に基ゔく圧力の急激な低下が みられるが，No. 3 以下では樹脂温度の低下による圧力 の減少と重なり，明らかではない。この流動停止時間を 収縮率から求められる固化時間と比較するとFig. 6 に示 したとおり加熱筒温度および金型温度が上䄯するほどそ の差は大きくなる。Sors ${ }^{8)}$ に従えば金型内の樹脂温度の 時間的変化は平板に対して(1)式で与えられる。ここで $\lambda^{2)}$ は熱伝導率 $\left(\mathrm{cal} / \mathrm{cm} \cdot \mathrm{sec} \cdot{ }^{\circ} \mathrm{C}\right) V$ ，は比容積 $\left(\mathrm{cm}^{3} / \mathrm{gr}\right)$, $h$ は成形品厚み $(\mathrm{cm}), Q$ は時間 $t(\mathrm{sec})$ までに樹脂から 金型に移動する熱量 $(\mathrm{cal} / \mathrm{g}), T_{\boldsymbol{N}}$ は金型温度 $\left({ }^{\circ} \mathrm{C}\right), T_{R a V}$ は平均樹脂温度 $\left({ }^{\circ} \mathrm{C}\right)$ である。Qは(2)式で与えられ $C_{R a V}{ }^{5)}$ は樹脂の平均比熱 $\left(\mathrm{cal} / \mathrm{g} \cdot{ }^{\circ} \mathrm{C}\right) ， T_{R 0}$ は時間 0 における樹 脂温度 $\left({ }^{\circ} \mathrm{C}\right), T_{R t}$ は時間 $t$ における樹脂温度 $\left({ }^{\circ} \mathrm{C}\right)$,

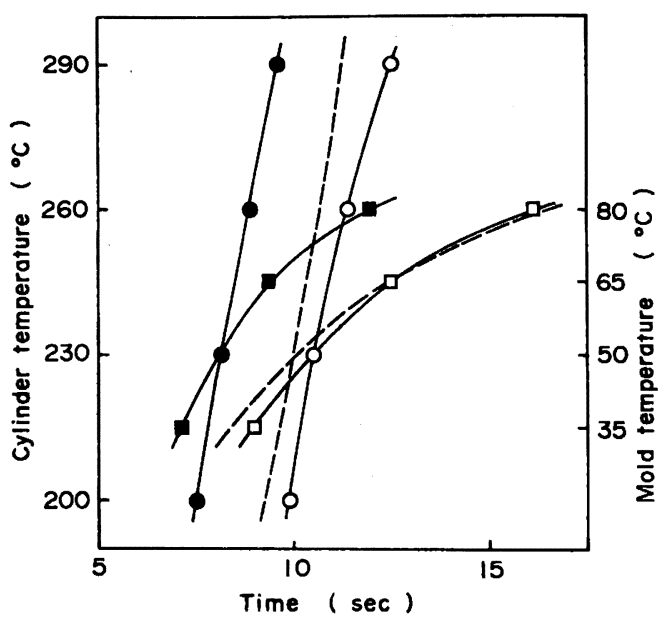

Open circles and squares show solidification times. Solid circles and squares show stop times of flow. Broken line shows calculated solidification time.

Fig. 6. Effects of cylinder temperature and mold temperature on solidification times and stop times of flow at No. 2 position and their comparison with calculated values. 
$\Delta H_{\mathbf{u}}{ }^{6)}$ は樹脂の融解潜熱 $(\mathrm{cal} / \mathrm{g})$ である。

$$
\begin{aligned}
t & =\frac{Q h^{2}}{8 \lambda V_{v}\left(T_{R a V}-T_{u}\right)} \\
Q & =C_{R a V}\left(T_{R 0}-T_{k t}\right)+\Delta H_{u}
\end{aligned}
$$

樹脂の流動停止時間が結晶化の開始に，前記固化時間 が結晶化の完了に相当すると考えれば，その差は結晶化 時間となり，(1)式で $Q=\Delta H_{u}\left(T_{\text {RaV }}=117^{\circ} \mathrm{C}\right)$ とすれば 計算により求めることが可能である。この場合実測值は 計算値の $1 / 4$ しかなく著しく相違するが，これは流動の 停止時間と計算される結晶化開始時間とが著しく異なる ためで，計算値をもとにして実测された時間内に結晶化 しうる樹脂の厚みを求めると約 $1.25 \mathrm{~mm}$ となり, 流動 圧の実测值と計算值との比較の場合7) と同じように固化 した表面層を考虑すればうなずける值である。また計算 された結晶化の完了時間は Fig. 6 の破線のとおりで実 測の固化時間とよい一致を示す。

\section{3 収樎率の大きさと異方性}

成形収縮率は成形条件および成形品内の位固による密 度変化が無視できるときは成形品重量で整理されるもの と考えられる。保持圧力の成形品密度に及ぼす影響はほ とんどなく，保持圧力が非常に小さいときはゲイト近傍 においてわずかに小さく，また成形品末端においてはわ ずかに増加する傾向を示し, 保持圧力が大きく成形品厚 みが明らかに増大するときは密度もわずかに増加する傾 向を示す。加熱筒温度および金型温度による密度変化は 第 2 報1) の結果とよく一致し成形方法および保持圧力の 影響はみられない。

成形品重量に対して MD と TD の収縮率の平均値を 示せば Fig. 7 のとおりで金型温度を除く成形条件に関係 なく収縮率が成形品重量で整理されることがわかる。ま

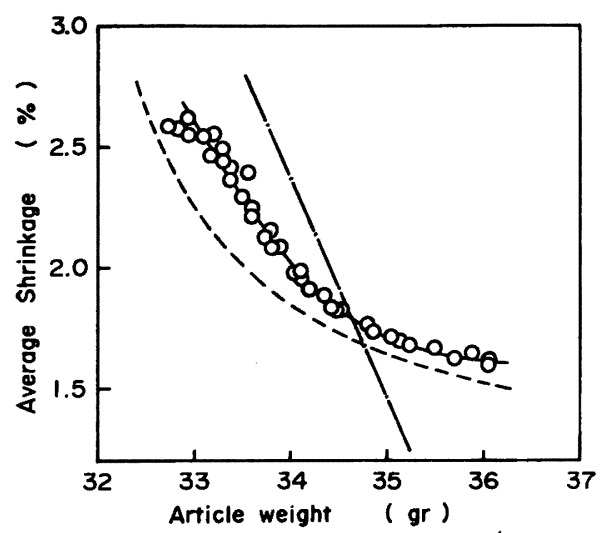

Broken line shows previous data and chain line shows calculated ones from article weight and density.

Fig. 7. Relationship between average mold shrinkages and article weights.
た平均の成形品厚みも成形品重量で整理されるが, 本報 の結果を第 2 報1 のそれと比較すると同一重量に対して わずかに厚くそれに伴って収縮率が増大している。

収縮率の異方性のパラメーターとして収縮率比 (TD /MD) を成形品重量に対して示せば Fig. 8 および 9 の とおりとなり,成形方法により異なった結果が得られる。

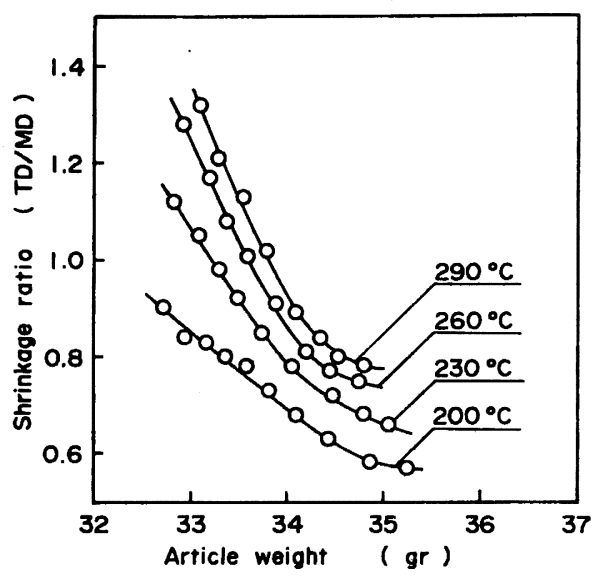

Molding conditions

Mold temperature: $50^{\circ} \mathrm{C}$, Cushion stroke: $10 \mathrm{~mm}$

Fig. 8. Effects of article weights and cylinder temperatures on anisotropies of mold shrinkages.

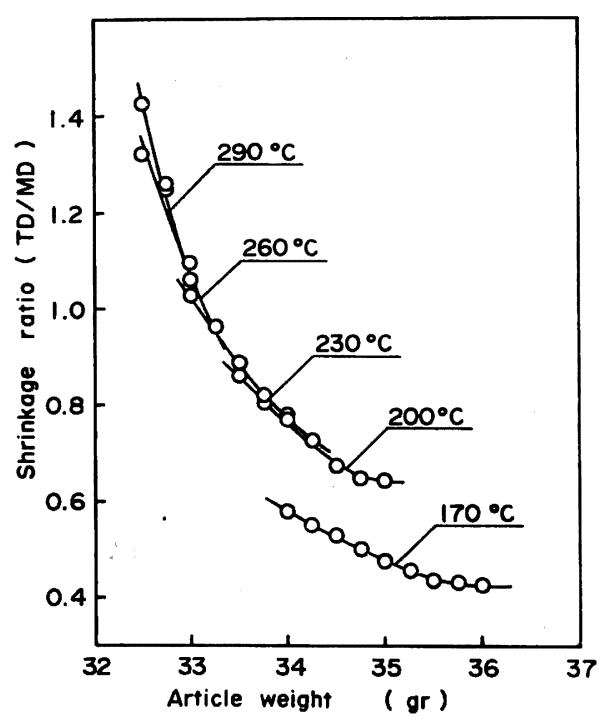

Molding conditions

Cushion stroke: $0 \mathrm{~mm}$, Mold temperature: $50^{\circ} \mathrm{C}$

Fig. 9. Effects of article weights and cylinder temperatures on anisotropies of mold shrinkages. 
高分子化学 (Kobunshi Kagaku), Vol. 28, No. 319, pp. 864-868 (Nov., 1971)

一般に収縮率比は成形品重量の増加とともに減少し，ま た加熱筒温度が低いほど減少することから初期充てん過 程の流動配向ばかりではなく保持圧力での補充過程も配 向に大きな影響を及ぼしていると推察される。同一成形 条件下での初期充てん量の影響では初期充てん量が少な いときは収縮率比が小さく，初期充てん量の増加ととも に収縮率比が増大して供給量 39〜41 mm でほぼ一定の 値となり,それ以上の量では逆に低下寸る。このことは初 期充てん量が少ないときは保持圧力で充てんが完了する ので充てんに時間を要し，この間に樹脂温度が低下して 配向が起こりやすく，一方初期充てん量が多く成形品重 量が増加するときは補充による樹脂量の増加を伴い，こ れはかなり樹脂温度が低下してからの流動となるので大 きな配向が生じたのではないかと推察される。Fig. 9 に 示した収縮率の異方性の加熱筒温度による変化は, 適正 成形品重量籁囲では $200 \sim 290^{\circ} \mathrm{C}$ の加熱筒温度で 1 本の曲 線で表わされるのに対し，クッションを用いた成形方法 では明らかに異なった曲線を示しており,成形品内の配 向が異なることを暗示している。

\section{4. 結 論}

成形品の収縮率は成形過程での金型キャビティー内の 樹脂圧力挙動を反映して成形方法拉よび成形条件により
異なる。保持圧力の大きさと長さに影響を与えるクッシ ヨン量, 初期充てん量, スクリュー前進時間抽よび保持 圧力の大きさは成形収縮を論ずるにあたって無視でき ずこれらはキャビティー内に充てんされた樹脂量を示 す成形品重量を仲介として收縮率の大きさを変えるばか りかその異方性をも強く支配している。また金型内の樹 脂圧力挙動と収縮率との関係から得られる樹脂の固化時 間は計算によって得られる結晶化完了時間と比較的よい 一致を示す。

付記 本報は第20回高分子学会年次大会（昭和46年 5 月28日，東京）に扔いて講演。

\section{文献}

1) 天野 修：高化，28, 493 (1971)

2) 天野 修: 高化, 28, 856 (1971)

3) L. Sors: Plastic Mold Engineering, 96 (1967)

4) K. Eiermann: Kunststoffe, 55, [5], 335 (1965)

5) B. Wunderlich: J. Polymer Sci., 24, 201 (1957) R. G. Griskey: SPE, Tech. Papers (ANTEC), 14, 546 (1968)

6) B. Wunderlich: J. Polymer Sci., 24, 201 (1957)

7) 天野 修：第19回高分子討論会講演要旨, 1105 (1970)

高せん断力による高密度ポリエチレンの物性変化

（受付1971年 7 日15日・掲載決定1971年 9 月10日）

木下洋一*・中村広一*・高倉 誠*・森本晴生*・春日孝夫*・神永 剛*

\begin{abstract}
要 旨われわれはメカノケミカル的な処理を工業的規模に応用して, 試料に高密度ポリエチレ ンを用い，熱と機械的せん断力によって分子量および分子量分布の調節を試み，この場合の物性変 化を検討した。使用機器は高速 2 軸ミキサー, CIM-120である。

その結果, 直接重合試料との比校で処理試料は, 分子量分布については高分子量側が減少してょ り分散の狭いものに変わり, 同一 $\eta_{\mathrm{s}} \mathrm{p} / C$ の比較でメルトインデックスは小となり, 同一数平均分子 量の比較で溶液粘度は低くなる。また, 溶融城での活性化エネルギーは, 低密度と高密度ポリエチ レンの中間值をもつ。結論として, 処理により高分子量分子鎖の優先的切断が起こり, 平均分子量 の低下，分子量分布の狭化および長鎖分岐粠造の生成が推定された。
\end{abstract}

\section{1. 緒言}

ポリマーの加工時には, 加えられた応力の作用により

* 日産石油化学(株)高分子研究所 (千菜県市原市五井 南海岸11-1)
ポリマー塊はかなりの変形を受け，一部は高弹性変形と して，また一部は可塑性変形として働く。そのときの変 形が大であり，変形速度が大きいほどマクロ分子の化学 結合は破壊しフリーラジカルが生成する。生成したフリ ーマクロラジカルは複雑な連鎖過程に移ることが考えら 
by the computer simulation using finite element method. The results agreed well with those calculated by use of approximate analytical equations for two-component unit models reported in the preceding paper.

KEY WORDS Composite Material / Unit Model / Inhomogeneity Effect / Young's Modulus / Finite Element Method

\title{
Molding Conditions of High Density Polyethylene and the Pressure Behaviors of Resin in the Mold Cavity
}

\author{
by Osamu Amano*
}

[Kobunshi Kagaku, Vol. 28, No. 319, pp. 856-860 (Nov., 1971)]

Effect of holding pressure on the pressure behaviors of HDPE in the mold cavity during injection molding is studied. The resin pressure at the nozzle during the holding time is not always the same as the holding pressure shown in the pressure gauge mounted in the hydraulic oil circuit and strongly depends on the quantity of resin remaining at the front of the screw head in the heating cylinder (cushion volume) after completion of the injection.

The holding pressure has two roles; one is to supply the same quantity of the resin in the mold cavity as contracted by cooling. The other is to prevent the back flow of the resin during the holding time. With increasing holding pressures the article weight increases due to the increase of static pressure and the prolongation of pressure remaining time of the resin in the cavity. Under the same holding pressure, the increase of cylinder and mold temperatures leads same results, because the pressure loss from the nozzle to the gate is reduced.

The gate seal time and the stop time of flow of melt during the holding time can be estimated from the pressure profile at 20 and $70 \mathrm{~mm}$ from the gate.

KEY WORDS Injection Molding / HDPE / Pressure Profile / Cushion / Gate Seal Time /

* The Nisseki Plastic Chemical Co., Ltd. (15, Chidori-cho, Kawasaki, Kanagawa)

\section{Mold Shrinkages of High Density Polyethylene in Injection Molding}

\author{
by Osamu Amano*
}

[Kobunshi Kagaku, Vol. 28, No. 319, pp. 860—864 (Nov., 1971)]

Mold shrinkages of injection molded articles of HDPE depend remarkably on the pressure behaviors of the resin in the mold cavity, the molding procedures and the molding conditions. Effects of the cushion volume, the initial filling volume, the screw forward time and the holding pressure on the mold shrinkages were examined. In these cases cushion was used to keep the holding pressure constant during the holding time.

The holding pressure has large effects on the mold shrinkage and the static pressure in the pressure profile in the mold cavity. With increasing holding pressure the mold shrinkages in parallel and perpendicular directions to the flow of melt decrease and the anisotropy of the mold shrinkage inoreases,

Solidification time of the melt determined from the mold shrinkage and the pressure remaining time are prolonged with the increase of cylinder temperature and mold temperature. This solidification time agrees fairly well with calculated values. It seems that flow orientation which brings anisotropy of mold shrinkage is markedly governed by the resin temperature and the driving force during the filling process.

KEY WORDS Mold Shrinkages / HDPE / Pressure Profile / Solidification time /

* The Nisseki Plastic Chemical Co., Ltd. (15, Chidori-Cho, Kawasaki, Kanagawa) 